УДК 004.5+004.9:378.11

Карплюк Світлана Олександрівна

кандидат педагогічних наук, доцент, доцент кафедри прикладної математики та інформатики Житомирський державний університет імені Івана Франка, м. Житомир, Україна

ORCID ID 0000-0002-6988-0531

aleksa@zu.edu.ua

Вакалюк Тетяна Анатоліївна

кандидат педагогічних наук, доцент, доцент кафедри прикладної математики та інформатики Житомирський державний університет імені Івана Франка, м. Житомир, Україна

ORCID ID 0000-0001-6825-4697

neota@zu.edu.ua

\title{
ОГЛЯД ФУНКЦІОНАЛЬНИХ МОЖЛИВОСТЕЙ ПРОГРАМНОГО ЗАБЕЗПЕЧЕННЯ ДЛЯ УПРАВЛІННЯ ОСВІТНІМ ПРОЦЕСОМ ЗАКЛАДУ ВИЩОї ОСВІТИ
}

\begin{abstract}
Анотація. У публікації здійснено грунтовний аналіз основних тенденцій, які панують на ринку програмного забезпечення у напрямі реалізації ефективного інформаційнопедагогічного менеджменту в сучасних закладах вищої освіти. У статті наведено коротку ретроспективу становлення і розвитку автоматизованих систем управління. Проведено моніторинг наявних електронних продуктів, спрямованих на підвищення якості управління освітнім процесом у вищій школі, розробниками якого є вітчизняні комерційні IT-компанії і науково-дослідні установи. Визначено особливості розробки автоматизованих систем управління освітнім процесом, шляхом виокремлення їхніх переваг і недоліків залежно від рівня розробки. У статті визначено й описано функціональні можливості однієї 3 найпопулярніших інтегрованих автоматизованих інформаційно-аналітичних Webорієнтованих систем управління освітнім процесом закладів вищої освіти, яка розроблена фахівцями приватної фірми «Політек-СОФТ» й упроваджена в діяльність Житомирського державного університету імені Івана Франка. Стаття містить статистичні дані щодо кількості навчальних закладів на території Україні, які впровадили й активно використовують програмне забезпечення зазначеної ІТ-компанії. У публікації визначено конкретні переваги комплексної інформаційно-аналітичної системи «Деканат», які полягають у повноцінній та загальній автоматизації планування й обліку навчального процесу навчальних закладів будь-якого рівня акредитації, повній інформаційній сумісності 3 іншими програмними продуктами ПП «Політек-СОФТ», зручному конструкторі звітів та інтерфейсі, заощадженні коштів і людських ресурсів, можливості адаптації й повноцінного функціонування в будь-яких операційних системах. У публікації наведено деякі інформаційні відомості інструктивно-методичного характеру щодо використання комплексної інформаційно-аналітичної системи «Деканат» і зосереджено увагу на роботі іiі деяких робочих модулів. Попри це, у статті визначено напрями подальших досліджень, які полягають у висвітленні основних принципів функціонування інших найвідоміших автоматизованих інформаційно-аналітичних систем управління освітнім процесом навчальних закладів, які впроваджено у роботу вітчизняних вищих шкіл.
\end{abstract}

Ключові слова: інформаційно-аналітична Web-орієнтована система управління, освітній процес закладу вищої освіти.

\section{1. ВСТУП}

Постановка проблеми. На шляху інтеграції до європейського простору, перед нашою державою постає проблема реформування багатьох сфер людської діяльності, зокрема й освітньої. У цьому напрямі достатньо вагомим кроком щодо модернізації вітчизняної освітньої галузі стало прийняття Верховною Радою України Закону «Про вищу освіту», у якому наголошено на важливості реалізації якісних змін у системі 
підготовки висококваліфікованих фахівців і запровадження європейських стандартів вищої освіти. Така постановка питання зумовлює необхідність удосконалення процесу підготовки майбутніх спеціалістів, здатних до самостійного пошуку необхідної інформації й розв'язання завдань у своїй подальшій професійній діяльності, шляхом добору й упровадження інноваційних та ефективних технологій і систем управління освітнім процесом. Попри це, розв'язання даного завдання забезпечить досягнення стратегічної мети нашої держави, яка полягає в тому, щоб побудувати інформаційне суспільство, у якому кожен міг би створювати й накопичувати певну інформацію, мати до неї вільний доступ і можливість користуватися й обмінюватися нею. Цей підхід сприятиме стабільному розвитку сучасного суспільства й дозволить повною мірою реалізувати кожній людині свій розумовий і творчий потенціал [1].

Для того щоб розв'язати цю проблему, кожному закладу вищої освіти необхідно здійснити суттєві кроки у напрямі впровадження або проектування такої автоматизованої інформаційно-аналітичної системи, яка б змогла поєднати у собі роботу адміністративних, фінансових, господарських, навчальних та наукових підрозділів, а також сприяла інтеграції всіх процесів, які спрямовані на забезпечення належних умов щодо задоволення інформаційних потреб усіх учасників освітнього процесу, розвитку їх інтелектуального потенціалу, самореалізації і самовдосконалення, а також на якісну підготовку студентської молоді до повноцінної майбутньої професійної діяльності і життя в інформаційному суспільстві.

Важливість використання таких систем дедалі зростає, оскільки з активізацією впровадження Web-орієнтованих навчальних просторів, що є невід'ємною складовою сучасної системи вищої освіти, з'являється можливість здійснення управління, оптимізації та одержання аналітичної інформації щодо основної діяльності структурних підрозділів університету на засадах віддаленого доступу.

Аналіз численних праць вітчизняних і зарубіжних науковців у даній галузі засвідчують наявність значної кількості функціонуючих систем такого призначення, але немає єдиного підходу до проектування якісних автоматизованих систем управління процесом навчання у вищій школі. 3 огляду на це, проблема створення таких Web-pecyрсів, які дозволяють контролювати освітній процес і сприяють його ефективності, надає актуальності окресленому питанню, як такому, що має соціальну значущість.

Аналіз останніх досліджень і публікацій. Результати досліджень праць відомих науковців (Б. Л. Агранович, Л. М. Алфьорова, І. В. Аржанова, Ю. І. Бєляєв, В. Ю. Биков, Д. І. Бобровський, М. О. Вінник, І. В. Герасименко, О. О. Глущенко, В. Г. Гриценко, А. М. Гуржій, Е. М. Котов, В. С. Кривцов, Н. А. Кудас, А. С. Кулик, М. С. Львов, Л. П. Лясковський, К. В. Мирна, Н. В. Нечипорук, Р. А. Серебряков, Т. В. Січко, О. В. Співаковський, О. М. Спірін, І. В. Стеценко, Д. Ю. Столяров, Ю. Г. Тарасіч, А. М. Тихонов, Ю. В. Триус, Я. Б. Федорова, В. М. Філіпов, А. М. Целих, Н. М. Чаловська, А. Г. Чухрай, Д. С. Щедролосьєв та інші) суттєво вплинули на становлення і розвиток сучасних автоматизованих систем управління навчальним процесом, але 3 огляду на сучасні тенденції щодо організації освітнього процесу у закладах вищої освіти виникають нові можливості проектування ефективних і надійних інформаційно-аналітичних Web-орієнтованих систем, які будуть поєднувати в собі методичні, навчальні та інформаційні ресурси.

У цьому контексті, варто зазначити особистий внесок українських науковців $\mathrm{i}$ дослідників, серед яких: В. Ю. Биков [1], М. С. Львов [2], Р. А. Серебряков [3], О. В. Співаковський [4], Ю. В. Триус [5] та інші.

Аналіз праць цих та інших науковців засвідчив, що попри накопичення певного досвіду дослідження проблеми проектування й упровадження інформаційно- 
аналітичних Web-орієнтованих систем управління у процес навчання вищої школи, низка аспектів потребує подальшого вивчення, зокрема недостатньо висвітлено їх характерні особливості та функціональні можливості.

Мета статті. Моніторинг найвідоміших інформаційно-аналітичних Webорієнтованих систем управління освітнім процесом, які впроваджено у вищі школи України й окреслення доцільності їх використання шляхом визначення переваг i недоліків. Здійснення аналізу функціонування основних робочих модулів однієї з таких систем, яка впроваджена й активно використовується у роботі Житомирського державного університету імені Івана Франка (комплексна інформаційно-аналітична система «Деканат», розроблена фахівцями приватної IT-компанії «Політек-СОФТ» [6]).

\section{2. МЕТОДИ ДОСЛІДЖЕННЯ}

Під час дослідження використовувались такі методи: аналіз теоретичних та Інтернет-ресурсів, зокрема, вивчення передового вітчизняного i зарубіжного педагогічного досвіду й досвіду розробки Web-pecyрсів навчально-управлінського призначення, аналіз результатів упровадження Web-орієнтованих систем управління в освітній процес закладів вищої освіти.

\section{3. РЕЗУЛЬТАТИ ДОСЛІДЖЕННЯ}

Аналіз основних понять дослідження. Аналізуючи методи управління освітнім процесом у вищих навчальних закладах, нами зроблено висновок, що ефективним шляхом забезпечення якісного менеджменту в сучасному інформаційно-орієнтованому виші $\epsilon$ впровадження й активне використання інформаційно-аналітичних Webорієнтованих систем. Робота таких ресурсів зорієнтована на повну автоматизацію й упорядкування усіх структурних підрозділів вищої школи, раціоналізацію інформаційних потоків у ній, а також забезпечення процесу розвантаження співробітників вищого навчального закладу від громіздкої паперової роботи.

Перші ідеї створення автоматизованих систем управління з'явилися у 1959 році і належать видатному радянському кібернетику А. І. Китову [7]. Наступним кроком у цьому напрямі можна вважати роботи академіка В. М. Глушкова, основною метою яких була повна автоматизація багатьох виробничих процесів республіканського рівня [8].

Щодо проектування систем управління освітнім процесом, то перші спроби було зроблено у 1969 році у межах проекту «АСУ ВУЗ» [9]. Але відсутність теоретичної бази з управління вищим навчальним закладом і достатньо низький рівень розвитку комп'ютерної техніки не давали можливості розробити і реалізувати загальну модель системи організаційного управління вищої школи, тому кожна група розробників намагалась відображати потреби конкретного навчального закладу на засадах ентузіазму або комерціалізації [10].

На сьогоднішній день ринок програмного забезпечення щодо реалізації ефективного управління освітнім процесом закладів вищої освіти, зосереджено в околі програмних продуктів вітчизняних комерційних IT-компаній, державних науководослідних інститутів та аматорських колективів співробітників ВНЗ. Серед таких розробників найвідомішими є: НДІ прикладних інформаційних технологій; ТОВ «Комп'ютерні інформаційні технології»; Херсонський державний університет; Національний університет «Львівська політехніка»; Хмельницький національний університет; Львівський інститут банківської справи; ПП «Політек-СОФТ»; Вінницький національний аграрний університет (рис. 1). 


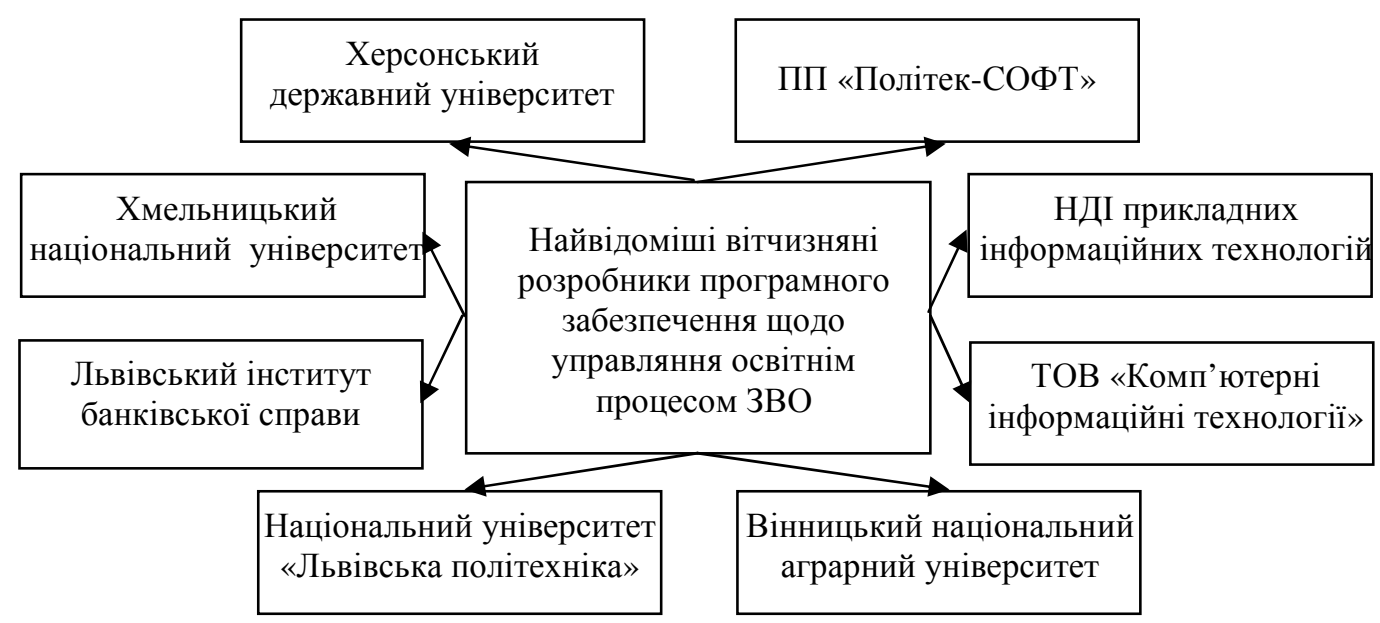

Рис. 1. Найвідоміші розробники програмного забезпечення щзодо реалізації ефективного управління освітнім прочесом закладів вищої освіти в Украӥні

Попри популярність спроектованих i впроваджених автоматизованих інформаційно-аналітичних Web-орієнтованих систем управління освітнім процесом у діяльність сучасних закладів вищої освіти, варто зауважити, що залежно від рівня розробки, вони мають низку характерних особливостей, а також свої переваги та недоліки, які подано у таблиці 1.

Таблиия 1

Особливості розробки автоматизованих систем управління освітнім процесом

\begin{tabular}{|c|c|c|}
\hline $\begin{array}{c}\text { Рівень } \\
\text { розробки }\end{array}$ & Недоліки & Переваги \\
\hline $\begin{array}{l}\text { Незалежна } \\
\text { розробка }\end{array}$ & $\begin{array}{l}\text { - } \quad \text { надмірна комерціалізація; } \\
\text { - } \text { надлишкова універсальність; } \\
\text { - } \text { складність налаштування; } \\
\text { - } \quad \text { громіздкий та незрозумілий } \\
\quad \text { інтерфейс }\end{array}$ & $\begin{aligned} \text { - } & \text { якісна документованість; } \\
\text { - } & \text { сервісна та консультаційна підтримка; } \\
\text { - } & \text { широкий набір функціональних } \\
& \text { можливостей }\end{aligned}$ \\
\hline $\begin{array}{l}\text { Індивідуальна } \\
\text { розробка }\end{array}$ & $\begin{array}{ll}\text { - } & \text { менша стійкість; } \\
\text { - } & \text { залежність від персонального } \\
& \text { супроводу своїми } \\
& \text { розробниками; } \\
\text { - } & \text { неякісна документованість }\end{array}$ & $\begin{array}{ll}\text { - } & \text { точніша відповідність специфічним } \\
& \text { умовам та вимогам вишу; } \\
\text { - } & \text { більш гнучкіша й оперативніша реакція } \\
& \text { щодо змін у законодавстві; } \\
- & \text { зручність для використання персоналом } \\
& \text { певного конкретного закладу вищої освіт }\end{array}$ \\
\hline
\end{tabular}

В основі роботи всіх інформаційно-аналітичних Web-орієнтованих систем, які спроектовані вищезазначеними установами, лежить один і той же принцип, про який наголошено у низці нормативних документів - принцип доступності до будь-якого роду інформації [11]. Проте, кожна із систем має свою унікальність. Для того, щоб мати уявлення про їхню роботу і чіткіше розуміти основні особливості такого роду електронних продуктів, проаналізуємо функційні можливості пакету програм «Деканат», що розроблений фахівцями ПП «Політек-СОФТ» та вдало впроваджений у роботу Житомирського державного університету імені Івана Франка.

Основна мета цього пакету програм - повноцінна і загальна автоматизація планування й обліку навчального процесу навчальних закладів будь-якого рівня акредитації [6]. За даними, які розміщені на офіційному сайті ПП «Політек-СОФТ», кількість впроваджень програмного забезпечення зазначеної компанії на території Україні складає 504 клієнти [6]. Крім Житомирського державного університету імені 
Івана Франка, цей продукт впроваджено у роботу значної кількості закладів освіти різних рівнів акредитації і форм власності багатьох регіонів нашої держави (рис. 2).

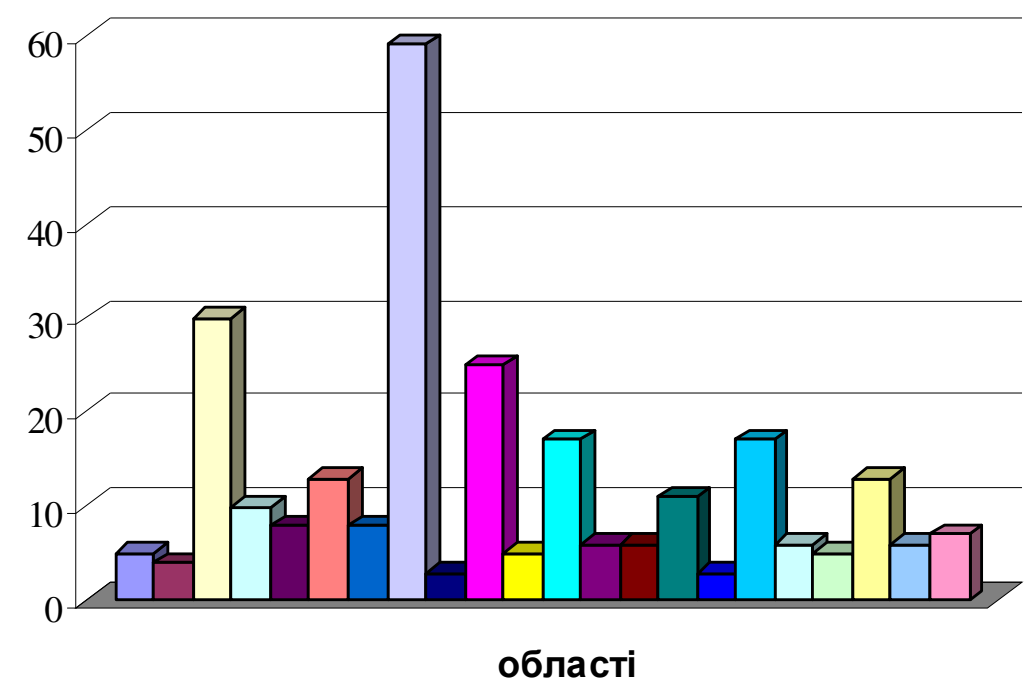

$\square$ Вінницька
$\square$ Волинська
$\square$ Дніпропетровська
$\square$ Житомирська
$\square$ Закарпатська
$\square$ Запорізька
$\square$ Івано-Франківська
$\square$ Київська
$\square$ Кіровоградська
$\square$ Львівська
$\square$ Миколаївська
$\square$ Одеська

Рис. 2. Кількість закладів освіти України, які використовують програмні продукти ПП «Політек-СОФТ»

Пакет програм «Деканат» містить взаємозалежні модулі. Дамо коротку характеристику кожного із них:

1. Навчальний план. Програма для використання у навчальному відділі вищого навчального закладу. Спрямована на забезпечення якісного створення, редагування й обчислення кількісних показників у навчальних планах, отримання відповідної звітної документації, а також полегшення формування кількості вакансій педагогічного навантаження, відповідно до норм діючого законодавства. Ця програма надає можливість співробітникам закладу вищої освіти власноруч визначати години 3 консультативних, індивідуальних та залікових занять. Сюди також входять години із заліків, іспитів (усних чи письмових), державної атестації (державні іспити чи дипломні роботи), контрольних (самостійні, модульні тощо), розрахунково-графічних робіт, а також будь-яких інших видів навантаження для всіх форм навчання (денна, вечірня та заочна) [6].

2. Навчальний процес (Університет). Програма для використання у навчальному відділі вищої школи. Забезпечує відображення у базі даних структури усього навчального процесу ЗВО, обрахунок навантаження для кожного підрозділу (кафедри) і для закладу вищої освіти у цілому, реєстрацію даних щодо будь-якої категорії викладачів і співробітників. Попри це, ця програма сприяє полегшенню розподілу педагогічного навантаження між викладачами, яке відбувається шляхом автоматичного обрахунку загальної кількості годин за тиждень, семестр і навчальний рік кожного окремого викладача. Цей додаток уможливлює здійснення всебічного аналізу освітнього процесу у всьому закладі вищої освіти, а також генерування й друк усієї необхідної документації (Ф. У-4.01, педагогічне навантаження викладача, бюджет годин з певної дисципліни, загальний штат усіх кафедр тощо) [6].

3. Політек-Софт (далі ПС) - Кафедра-Web. Планування. Ця програма призначена для використання кафедрами вищої школи. Її робота грунтується на засадах використання Web-інтерфейсу, який повністю виключає необхідність здійснення робіт з іiї налагодження на кафедрах ЗВО. Особливістю цього додатку $є$ 
можливість розподілу усього педагогічного навантаження кафедри між усіма іiі членами [6].

4. ПC-Кафедра-Web. Виконання. Програма спроектована для користування кафедрами вишу. Як і додаток «ПC-Кафедра-Web. Планування», вона не вимагає проведення додаткових робіт щодо ії встановлення на кафедрах закладу вищої освіти. Вона надає можливість фіксації і проведення повного аналізу щодо виконання навантаження будь-якої кафедри протягом цілого навчального року [6].

5. Розклад. Дана програма призначена для складання розкладу навчальних занять у чіткій відповідності до навчального плану кожної конкретної спеціальності, педагогічного навантаження усіх викладачів 3ВО, а також із врахуванням можливостей аудиторного фонду [6].

6. ПC-Студент-Web. Цей додаток використовується дирекціями навчальнонаукових інститутів і деканатами факультетів вишу. Він базується на основі використання Web-iнтерфейсу, що, у свою чергу, не вимагає додаткової роботи щодо іiі встановлення на комп'ютери структурних підрозділів. Призначення цієї програми полягає у проведенні обліку студентів і усіх поточних подій, які фіксуються наказами (рух контингенту, зміна прізвища тощо), моніторингу успішності студентів (за усіма можливими системами оцінювання навчальних досягнень). Попри це, серед можливостей цієї програми є отримання звітів щодо розподілу студентів (Ф. 2-3 НК) та їх успішності (семестрові й річні відомості, статистика успішності, зведена відомість для додатку до диплому тощо) [6].

7. ПС-Додаток до диплому-Web. Ця програма спроектована як об єкт (Active $\mathrm{X})$, що має властивість автоматично завантажуватися в інтернет-браузер через мережу iз сервера. Вона надає можливість друкувати додатки до дипломів нового зразка відповідно до чинного законодавства. Принцип іiі роботи полягає в автоматичному отриманні усієї необхідної інформації для друку з бази даних, яка сформована програмою «ПС-Студент-Web» [6].

8. ПC-Академ. довідка-Web. Програма, що дозволяє формувати і друкувати академічні довідки студентів. Вона, на основі програми «ПС-Студент-Web», дозволяє автоматично отримувати 3 бази даних усю необхідну інформацію для друку для кожного конкретного студента [6].

У пакеті програм «Деканат», фахівцями ПП «Політек-СОФТ», крім зазначених модулів, створено додаткові програмні модулі, які сприяють розширенню можливостей функціонування програми «ПС-Студент-Web». Спробуємо дати їм коротку характеристику:

1. ПС-Журнал успішності-Web. Зазначений модуль дозволяє здійснювати фіксацію й аналіз поточної успішності студентів будь-якої академічної групи (поточний рейтинг і відвідування навчальних занять) зусиллями викладачів, які забезпечують навчальний процес, а також надає можливість віддаленого доступу до такого роду журналів усім студентам вишу. Програма може в автоматичному режимі калькулювати семестрові показники успішності та друкувати відповідні відомості [6].

2. Розширений аналіз успішності. Програма створена для забезпечення генерування спеціальних дванадцяти додаткових звітів, які надають можливість здійснювати розширений аналіз семестрової успішності студентів [6].

Попри окреслені програмні модулі, до складу Пакету додатково входить програма «ПС-Адміністратор». Ї̈̈ функції полягають у проведенні щоденного тестування, резервного копіювання, а також, за певної необхідності, відновлення усієї бази даних. Вона надає можливість закладу вищої освіти заощаджувати кошти, оскільки не потребує людських ресурсів щодо обслуговування систем управління базами даних [6]. 
Така структура й організація роботи Пакету програм «Деканат» забезпечує достатньо високу надійність збереження даних, а також їх достовірність. Попри це, варто зазначити, що повна інформаційна сумісність з іншими програмними продуктами ПП «Політек-СОФТ» забезпечує якісне імпортування даних, які вже були внесені до бази даних інших продуктів [6].

Ще однією 3 переваг цієї інформаційно-аналітичної системи $є$ iii зручний конструктор звітів. Він дозволяє створювати й редагувати вже існуючу звітну документацію, використовуючи HTML - мову розмітки гіпертексту. Звітні документи, згенеровані системою, можна додатково переглядати й редагувати перед відправкою на друк у програмах Microsoft Office Word, Microsoft Office Excel, а також у Інтернетбраузері відповідно до певних вимог [6].

Беззаперечною перевагою пакету програм «Деканат» $\epsilon$ iï україномовний інтерфейс, а також адаптованість і повноцінне функціювання в операційних системах Windows 95/98/ME/NT/2000/2003/XP/Vista/7 [6].

Використання додаткових web-сценаріїв забезпечує можливість доступу до цієї бази даних у межах окремих програм пакету 3 мережі Інтернет, а у ролі сервера управління базами даних використовується FireBird [6].

Повноцінне впровадження зазначеного програмного продукту у діяльність Житомирського державного університету імені Івана Франка розпочалось 3 вересня 2015 року. За цей короткий час автоматизована інформаційно-аналітична система «Деканат» зарекомендувала себе як надійна база 3 управління інформаційними потоками всіх структурних підрозділів університету, оскільки даний пакет побудований за клієнт-серверною технологією, що дозволяє безперешкодно встановлювати його на значну кількість комп`ютерів, які об`єднуються в локальну мережу й працюють з єдиною базою даних (це понад 12 машин). До роботи з пакетом програм «Деканат» можуть бути залучені як окремі працівники університету (методисти навчального відділу, секретарі деканатів або навчально-наукових інститутів та кафедр), так і будь-які інші учасники навчального процесу (викладачі та студенти).

Папка «Деканат» (рис. 3), яка, як правило, розміщена на «Робочому столі» кожного з таких комп'ютерів, містить інформацію про наявність активних робочих модулів програми, але ми хотіли б зосередити свою увагу на трьох, на наш погляд, найважливіших iï структурних компонентах, зокрема: «Навчальний процес», «Навчальний план» $\mathrm{i}$ «Розклад» [6].

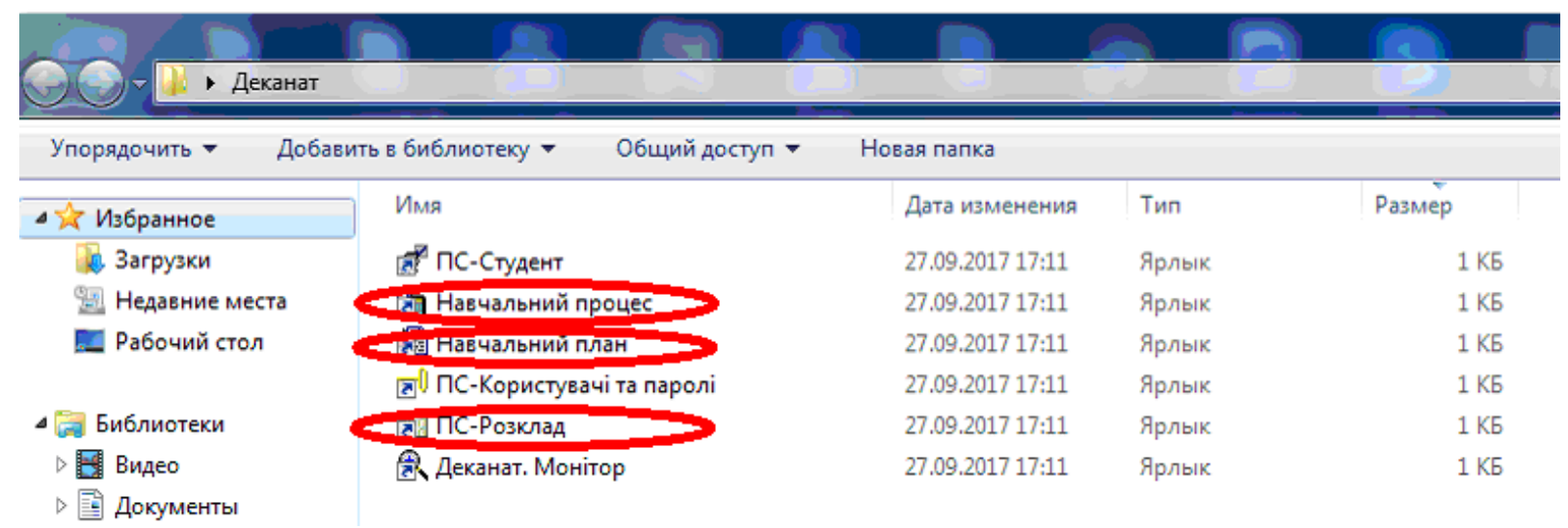

Рис. 3. Активні робочі модулі програми «Деканат» [6]

У процесі роботи з програмою, вхід до неї відбувається шляхом авторизації різного рівня користувачів у робочому вікні (рис. 4), шляхом уведення свого окремого логіна й пароля (у кожного структурного підрозділу університету вони різні). 


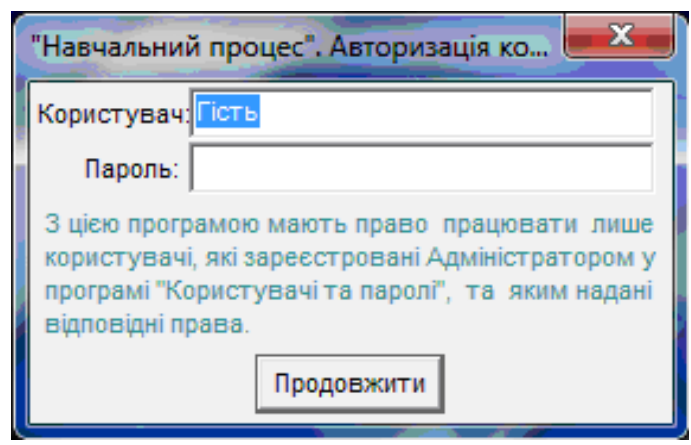

Рис. 4. Вікно авторизачії користувачів програми «Деканат» [6]

Після успішної авторизації (варто пам'ятати, що кожний окремий модуль програми потребує нової авторизаціі), у програмному модулі «Навчальний процес» (рис. 5) можна виконувати будь-які дії щодо підвищення ефективності управління освітнім процесом кожного структурного підрозділу й університету в цілому. Цей модуль передбачає зміну даних за такими вкладками: «Редагування»; «Структура» (коригування кількості робочих тижнів у семестрах); «Зведена сітка годин»; «Групи» (визначення номера групи, кількості студентів у ній, форм навчання студентів тощо); «Підгрупи» (поділ групи на підгрупи під час лабораторних занять, визначення кількості студентів у ній тощо), «Потоки» (об'єднання академічних груп у потоки для лекційних занять, переважно); «Викладачі» (внесення даних про викладачів університету) та «Розподіл навантаження» (закріплення викладача за дисципліною, групою або підгрупою).

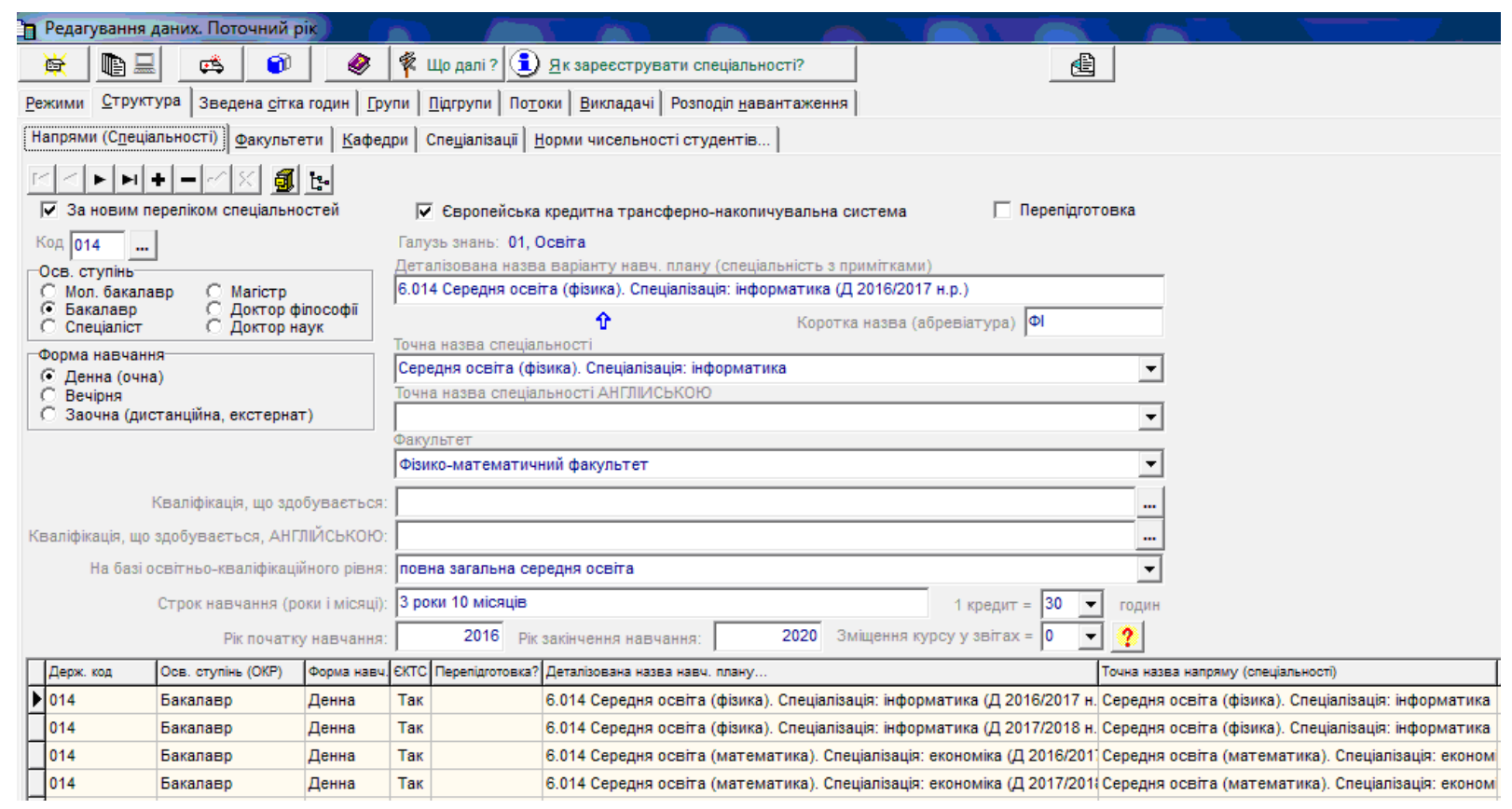

Рис. 5. Робоче вікно модуля «Навчальний прочес» програми «Деканат» [6]

Програмний модуль «Навчальний процес» взаємозв'язаний з, не менш значущим у пакеті програм «Деканат», модулем «Навчальний план», оскільки, так звана «прив'язка» викладача до дисципліни ніколи не відбудеться без внесення повного обсягу інформації щодо навчального плану кожної окремої спеціальності та курсу до 
загальної бази даних. Саме тому програмний модуль «Навчальний план» (рис. 6) є достатньо важливим у процесі управління освітнім процесом університету в цілому.

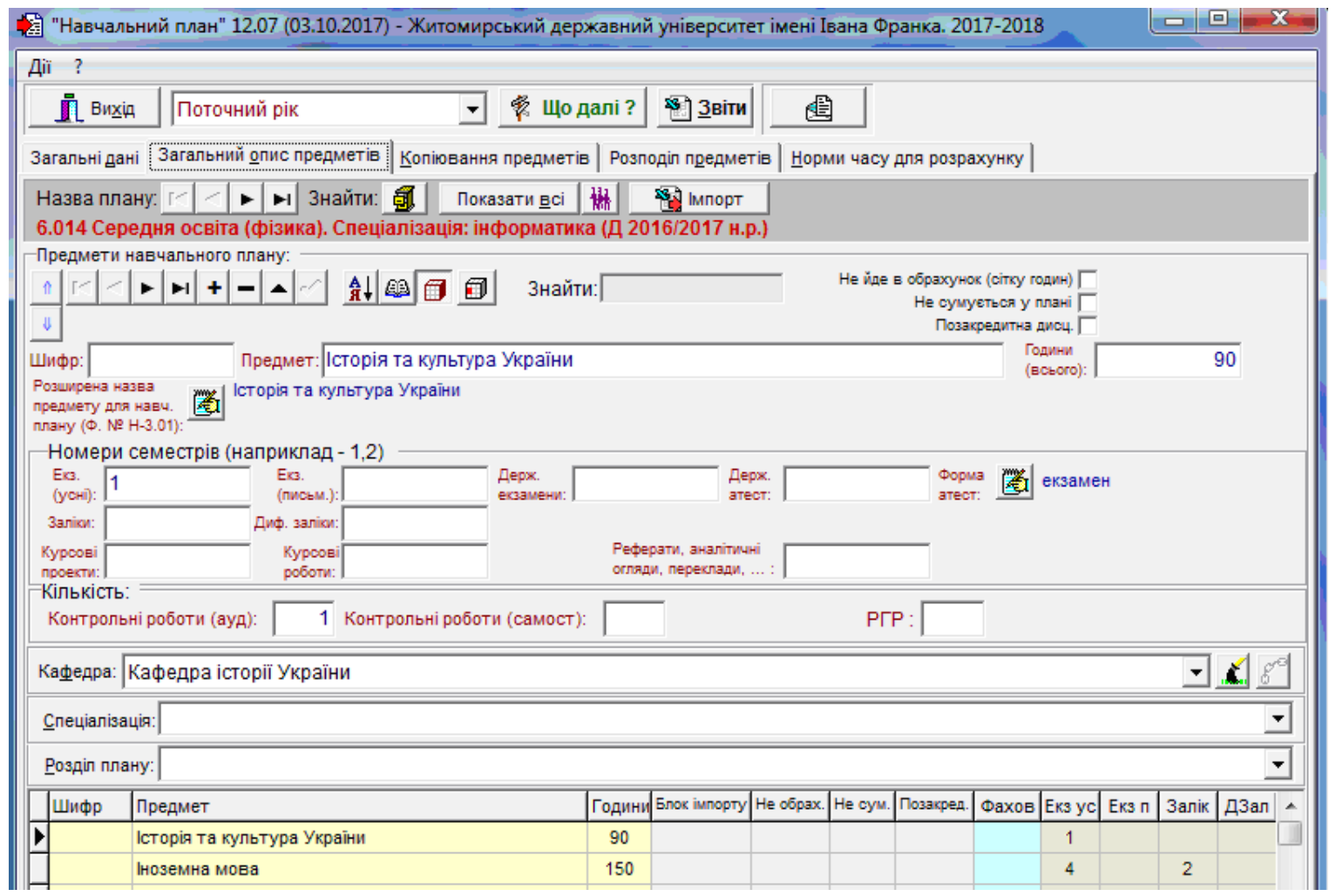

Рис. 6. Робоче вікно модуля «Навчальний план» програми «Деканат» [6]

Ще одним із достатньо важливих модулів, який перебуває у чіткій взаємодії 3 усіма іншими модулями інформаційно-аналітичної системи «Деканат» і забезпечує систематизацію усіх ㄲï процесів є програмний модуль «Розклад». Його активізація відбувається шляхом виклику робочого вікна (рис. 7).

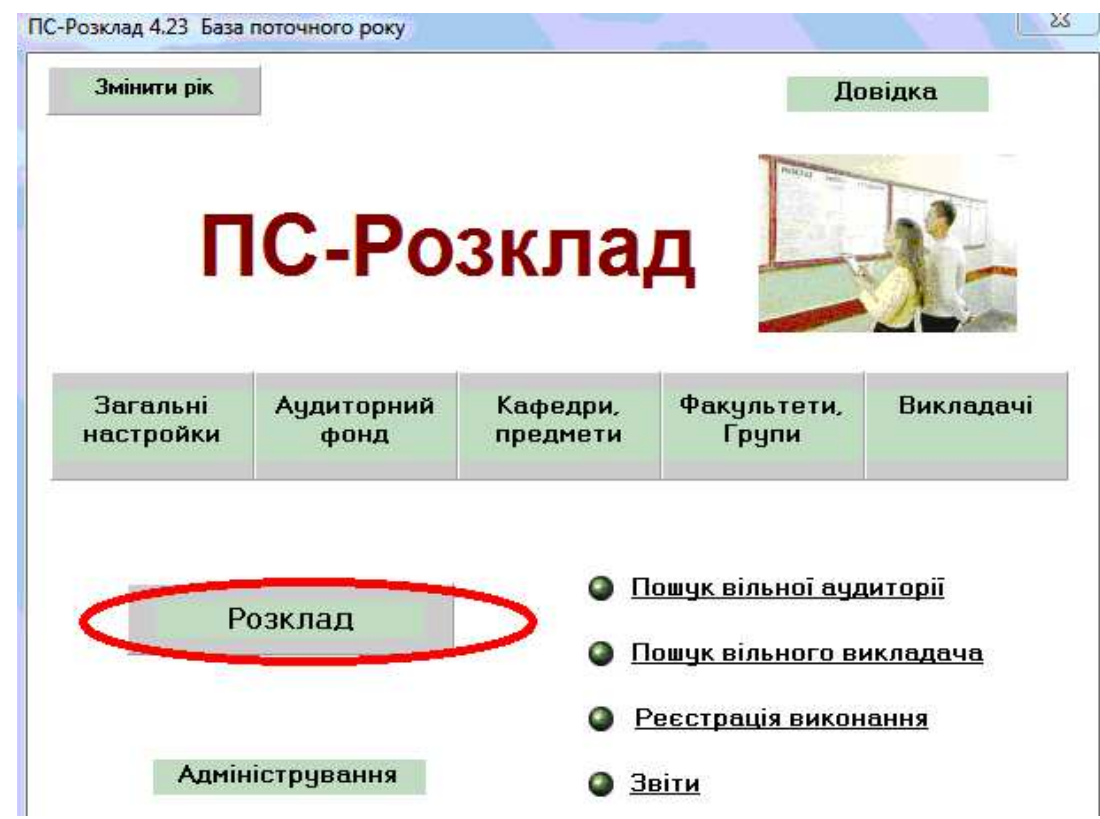

Рис. 7. Робоче вікно модуля «Розклад» програми «Деканат» [6] 
Функціональні можливості редактора розкладу дозволяють у чіткій послідовності (до моменту повної «вичитки») виконувати навантаження кожного окремого викладача й академічної групи у суворій відповідності до навчального плану, який визначає курс i спеціальність цієї групи (рис. 8). Попри це, даний редактор дозволяє здійснювати автоматичне закріплення аудиторій за певним заняттям, враховуючи їх зайнятість. У зв'язку з цим, так звані «накладки» або збіги аудиторного фонду повністю відсутні. Для зручності, можна застосовувати кольорові закріплення за певними заняттями або викладачами. Такий підхід дозволяе візуально швидко знаходити необхідний параметр і вносити потрібні зміни до загального розкладу.

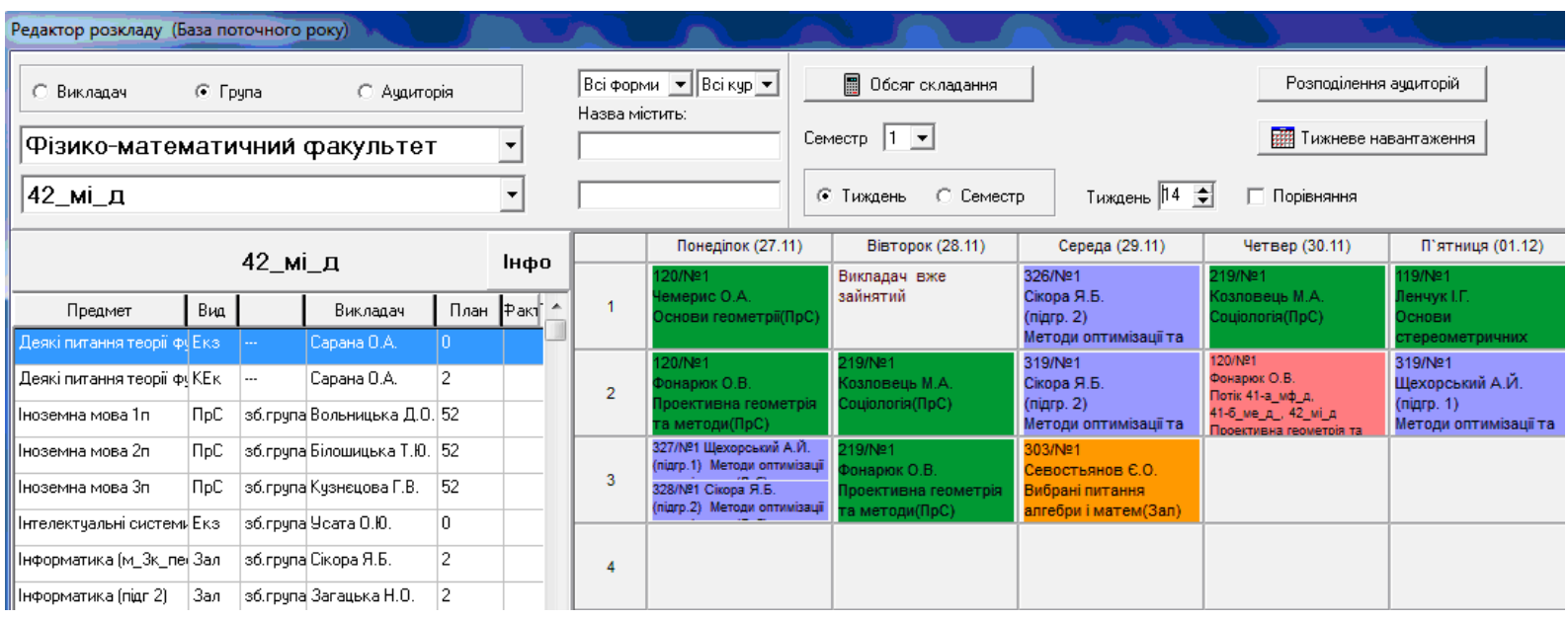

Рис. 8. Робоче вікно «Редактора розкладу» програми «Деканат» [6]

Позитивна риса даного програмного модулю полягає у вільному доступі до нього, будь-якого роду користувачів з мережі Інтернет. Даний процес відбувається за таким посиланням https://dekanat.zu.edu.ua/ (рис. 9).

$\leftarrow \rightarrow$ C

Житомирський державний університет імені Івана Франка

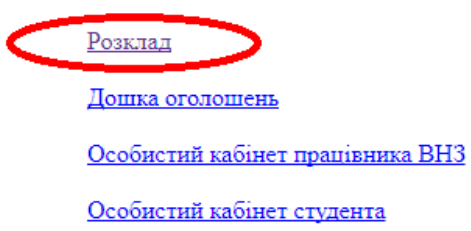

Рис. 9. Інтерфейс активізованого вікна доступу до електронного розкладу

Вибравши вкладку «Розклад», можна застосувати певний фільтр (або прізвище, ім'я, по батькові викладача, або номер групи) й отримати всю необхідну інформацію щодо розкладу занять у певний календарний період від першої до останньої «пари» (рис. 10). 


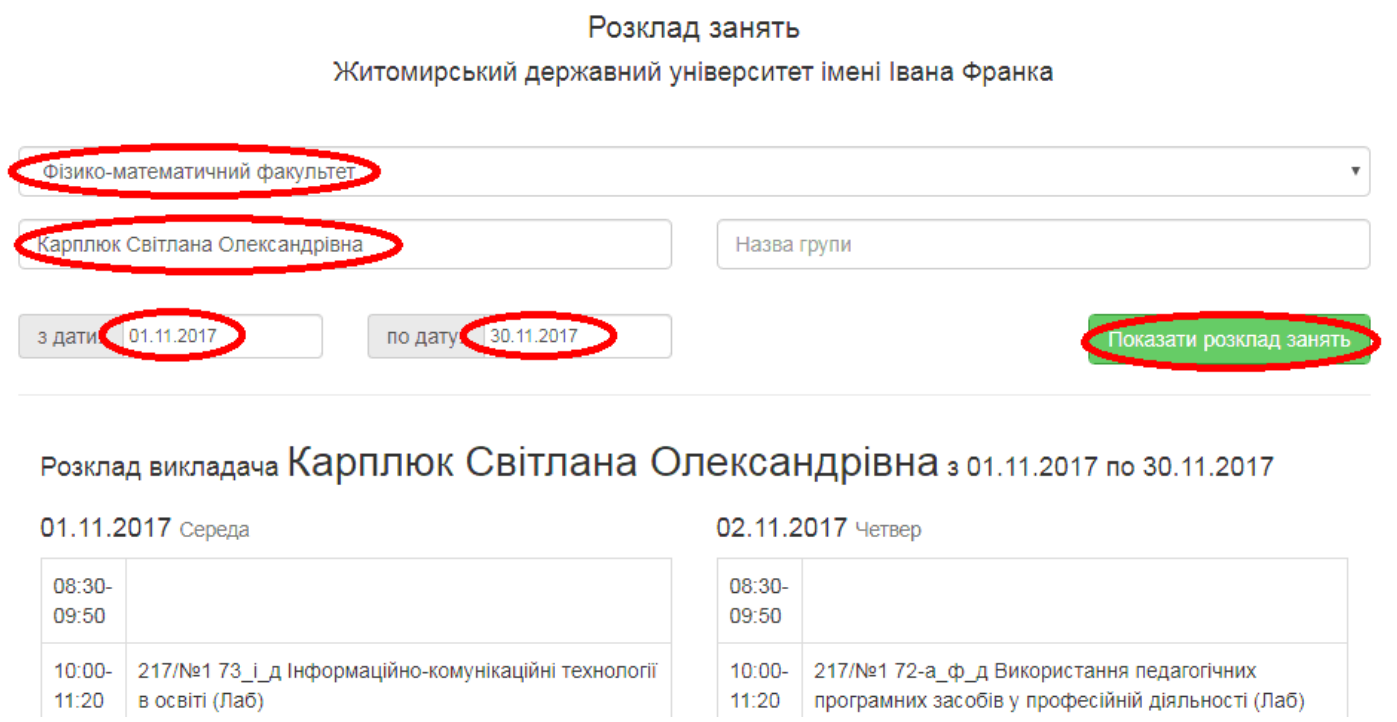

Рис. 10. Інтерфейс активізованого вікна «Розклад занять.

На нашу думку, використання електронного розкладу дозволяє вести чіткий розподіл навчального навантаження по конкретному викладачу, по кафедрі, по факультету та університету в цілому, що дозволяє мінімізувати кількість помилок у розкладі, скорочує час і трудовитрати в плануванні навчального процесу, а також підвищує оперативність управління освітнім процесом, інформованість керівництва деканатів, навчально-наукових інститутів та університету.

\section{4. ВИСНОВКИ ТА ПЕРСПЕКТИВИ ПОДАЛЬШИХ ДОСЛІДЖЕНЬ}

У результаті аналізу функціональних можливостей пакету програм ПП «ПолітекСОФТ», можна стверджувати, що їхня робота спрямована на ефективність управління освітнім процесом закладу вищої освіти й забезпечення швидкого доступу до необхідної інформації, яка його супроводжує. Попри це, інформаційно-аналітична система побудована на засадах інформаційно-педагогічного менеджменту, основною метою якого є комплексна автоматизація процесів керування вищих шкіл усіх рівнів акредитації. Упровадження й використання такої програми в навчальному процесі суттєво піднімає рейтинг вишу на ринку освітніх послуг. Основні іiї переваги полягають в такому:

- усі програми встановлюються й підтримуються лише на сервері, а це означає, що не потрібно здійснювати додаткових підключень інших комп'ютерів у мережі вищого навчального закладу. До того ж, програмне забезпечення не потребує жодних дій щодо здійснення оновлення комп'ютерного парку або заміни операційних систем. Такий підхід спрощує впровадження й обслуговування усієї системи;

- відсутня необхідність «прив язки» оператора (диспетчера) до певного робочого місця, оскільки він має відповідні права доступу (працівник деканату, кафедри, викладач) і може працювати 3 програмами як з будь-якого комп ютера мережі вищого навчального закладу, так і власного домашнього комп'ютера;

- існує можливість вирішення проблеми територіальної віддаленості навчальних корпусів вищого навчального закладу, оскільки програма може функціонувати в умовах низької пропускної здатності мережі (наприклад, через модеми); 
- програми сприяють розширенню Інтернет-ресурсів вищої школи, шляхом внесення посилань на програми у Web-сторінку закладу вищої освіти.

Проте, поряд із значними перевагами зазначеного програмного продукту, є й певні недоліки, усунення яких значно підвищить його ефективність:

- система не надає можливостей розширення прав доступу різним категоріям користувачів (наприклад, налаштування інтерфейсу своєї особистої сторінки);

- система дещо перевантажена зайвими блоками і вкладками, які значною мірлю гальмують роботу з ними в цілому;

- відсутність програмних модулів, які визначають напрям наукової та виховної діяльності студентської молоді й викладачів (участь у науковому житті університету; організація дозвілля студентів; робота органів студентського самоврядування).

Напрямами подальших досліджень вважаємо окреслення принципів функціонування інших найбільш відомих автоматизованих інформаційно-аналітичних систем управління освітнім процесом, які впроваджено у роботу вітчизняних вищих шкіл, а також здійснення добору критеріїв і показників, за допомогою яких буде визначено напрям проектування власної інформаційно-аналітичної Web-орієнтованої системи управління процесом навчання фізико-математичного факультету 3 врахуванням усіх недоліків такого роду електронних продуктів.

\section{СПИСОК ВИКОРИСТАНИХ ДЖЕРЕЛ}

[1] В. Ю. Биков, Моделі організаційних систем відкритої освіти. Київ, Україна: Атіка, 684 с., 2009.

[2] М. Львов, О. Співаковський та Д. Щедролосьєв, "Інформаційна система управління вищим навчальним закладом як платформа реалізації управління академічним процесом", Вісник Харківського університету. Серія "Математичне моделювання. Інформачійні технологї. Автоматизовані системи управління", №1, с. 1-21, 2005.

[3] Р. Серебряков та Л. Лясковський, "Особливості впровадження автоматизованої системи управління вищим навчальним закладом", Науково-технічний збірник "Вісник Національного транспортного університету", №17, с. 7-9, 2008.

[4] О. Співаковський, О. Глущенко, Н. Кудас, Я. Федорова, Н. Чаловська та Д. Щедролосьєв, Інформаційні технології в управлінні вищими навчальними закладами. Херсон: Айлант, 152 с., 2005.

[5] Ю. Триус, І. Стеценко, І. Герасименко та В. Гриценко, "Інформаційно-аналітична система управління навчальним процесом ВНЗ", Збірник наукових прац̧ь "Інформаційні технологї в освіті", №9, с. 40-49, 2011.

[6] "Програмне забезпечення для вищих навчальних закладів України", Політек-СОФТ, 2017. [Електронний ресурс]. Доступно: http://www.politek-soft.kiev.ua/.

[7] Й. Петрович та Ю. Римар, "Інформаційні системи управління навчальним процесом у ВНЗ: порівняльний аналіз", Вісник Національного університету "Львівська політехніка", №735, с. 167$175,2012$.

[8] В. Ямпольский, О. Петров, И. Чудинов и В. Валентинов, Автоматизация управления высшей школой. Воронеж: Издательство Воронежского университета, 176 с., 1987.

[9] А. Целых, Д. Бобровский и Э. Котов, Комплексная автоматизация управления вузом на основе ACУ "Университет". Таганрог: Изд-во ТТИ ЮФУ, 126 с., 2009.

[10] А. Гуржий, В. Кривцов, А. Кулик, Е. Мирная, Н. Нечипорук и А. Чухрай, Информационноаналитические модели управления техническими высшими учебными заведениями. Харьков: Нац. аэрокосм. ун-т "Харьковский авиационный институт", 387 с., 2004.

[11] С. Карплюк, "Інформаційно-педагогічний менеджмент вищої школи: сучасний стан та перспективи розвитку", Науковий вісник Ужгородського університету. Серія: Педагогіка. Соцііальна робота., №241, с. 122-125, 2017.

Матеріал надійшов до редакиії 01.12.2017p. 


\title{
ОБЗОР ФУНКЦИОНАЛЬНЫХ ВОЗМОЖНОСТЕЙ ПРОГРАММНОГО ОБЕСПЕЧЕНИЯ ДЛЯ УПРАВЛЕНИЯ ОБРАЗОВАТЕЛЬНЫМ ПРОЦЕССОМ УЧРЕЖДЕНИЯ ВЫСШЕГО ОБРАЗОВАНИЯ
}

\author{
Карплюк Светлана Александровна \\ кандидат педагогических наук, доцент, доцент кафедры прикладной математики и информатики \\ Житомирский государственный университет имени Ивана Франко, г. Житомир, Украина \\ ORCID ID 0000-0002-6988-0531 \\ aleksa@zu.edu.ua \\ Вакалюк Татьяна Анатольевна \\ кандидат педагогических наук, доцент, доцент кафедры прикладной математики и информатики \\ Житомирский государственный университет имени Ивана Франко, г. Житомир, Украина \\ ORCID ID 0000-0001-6825-4697 \\ neota@zu.edu.ua
}

\begin{abstract}
Аннотация. В публикации осуществлено основательный анализ основных тенденций, господствующих на рынке программного обеспечения в направлении реализации эффективного информационно-педагогического менеджмента в современных учреждениях высшего образования. В статье приведена краткая ретроспектива становления и развития автоматизированных систем управления. Проведен мониторинг имеющихся электронных продуктов, направленных на повышение качества управления образовательным процессом в высшей школе, разработчиками которого являются отечественные коммерческие ITкомпании и научно-исследовательские учреждения. Определены особенности разработки автоматизированных систем управления образовательным процессом, путем выделения их преимуществ и недостатков в зависимости от уровня разработки. В статье определены и описаны функциональные возможности одной из самых популярных интегрированных автоматизированных информационно-аналитических Web-ориентированных систем управления образовательным процессом высших учебных заведений, которая разработана специалистами частной фирмы «Политек-СОФТ» и внедрена в деятельность Житомирского государственного университета имени Ивана Франко. Статья содержит статистические данные по количеству учебных заведений на территории Украины, которые внедрили и активно используют программное обеспечение указанной IT-компании. В публикации определены конкретные преимущества комплексной информационно-аналитической системы «Деканат», которые заключаются в полноценной и общей автоматизации планирования и учета учебного процесса учебных заведений любого уровня аккредитации, полной информационной совместимости с другими программными продуктами ITкомпании «Политек-СОФТ», удобном конструкторе отчетов и интерфейсе, сбережении средств и человеческих ресурсов, возможности адаптации и полноценном функционировании в любых операционных системах. В публикации приведены информационные сведения инструктивно-методического характера по использованию комплексной информационно-аналитической системы «Деканат» и сосредоточено внимание на работу ее некоторых рабочих модулей. Кроме того, в статье определены направления дальнейших исследований, которые заключаются в освещении основных принципов функционирования других наиболее известных автоматизированных информационно-аналитических систем управления образовательным процессом учебных заведений, которые внедрены в работу отечественных вузов.
\end{abstract}

Ключевые слова: информационно-аналитическая Web-ориентированная система управления; образовательный процесс высшего учебного заведения.

\section{REVIEW OF SOFTWARE FUNCTIONAL OPPORTUNITIES FOR MANAGING EDUCATIONAL PROCESS OF HIGHER EDUCATION}

Svitlana O. Karpliuk

$\mathrm{PhD}$ of Pedagogical Sciences, Associate Professor,

Associate Professor of the Department of Applied Mathematics and Computer Science

Zhytomyr Ivan Franko State University, Zhytomyr, Ukraine

ORCIDE ID 0000-0002-6988-0531

aleksa@zu.edu.ua 


\title{
Tetiana A. Vakaliuk
}

$\mathrm{PhD}$ of Pedagogical Sciences, Associate Professor

Associate Professor of the Department of Applied Mathematics and Computer Science

Zhytomyr Ivan Franko State University, Zhytomyr, Ukraine

ORCID ID 0000-0001-6825-4697

neota@zu.edu.ua

\begin{abstract}
The publication provides a thorough analysis of the main tendencies that prevail in the software market for implementing effective information and pedagogical management in modern higher education institutions. The article presents a brief retrospective of the formation and development of automated control systems. The monitoring of existing electronic products aimed at enhancing the quality of the educational management in higher school, developed by Ukrainianbased commercial IT-companies and research institutions, has been done. The peculiarities of development of automated control systems of educational process have been determined by distinguishing their advantages and disadvantages depending on the level of their development. The article describes the functionality of one of the most popular integrated automated information-analytical Web-oriented educational management systems of higher education institutions developed by the "Politek-SOFT" private company and implemented in the Zhytomyr Ivan Franko State University. The article contains statistical data on the number of educational institutions in Ukraine that have implemented and actively used the software of the specified IT company. The publication identifies the specific advantages of a comprehensive information and analytical system "Dean's Office" which consists of: the full and comprehensive automation of planning and accounting of educational process, full information interoperability with other software products of PE "Politek-SOFT", convenient report designer and interface, possibilities of adaptation and full-fledged functioning in any operating system. In addition, it saves money and human resources and is applicable to educational institutions of any level of accreditation. The authors provide some information on the methodical guidance on the use of a comprehensive information and analytical system "Dean's Office" and focus on the functioning of some of its working modules. The article outlines the direction of further research with the emphasis on the main principles of the functioning of other well-known automated informational and analytical systems of educational management that have been implemented at the national higher educational institutions.
\end{abstract}

Keywords: information-analytical Web-based management system; educational process of higher educational institutions.

\section{REFERENCES (TRANSLATED AND TRANSLITERATED)}

[1] V.Yu. Bykov, The models of open education organizational systems. Kyiv, Ukraine: Atika, 684 p. 2009. (in Ukrainian)

[2] M. Lvov, O. Spivakovskyi and D. Shchedrolosiev,"Management information system higher education institution as a platform for managing the academic process", Bulletin of Kharkiv National University, series «Mathematical modeling. Information technology. Automated control systems»", №1, p. 1-21, 2005. (in Ukrainian)

[3] R. Serebriakov and L. Liaskovskyi, "Features of introduction of the automated control system of higher educational institution", The National Transport University Bulletin: A Scientific and Technical Journal, №17, p. 7-9, 2008. (in Ukrainian)

[4] O. Spivakovskyi, O. Hlushchenko, N. Kudas, Ya. Fedorova, N. Chalovska and D. Shchedrolosiev, Information technology in the governance of higher education institutions.. Kherson: Ailant, 152 p., 2005. (in Ukrainian)

[5] Iu. Tryus, I. Stetsenko, I. Herasymenko and V. Hrytsenko, "Information-analytical system of management of educational process of the UNIVERSITY", Journal of Information Technologies in Education, №9, p. 40-49, 2011. (in Ukrainian)

[6] "Software for higher educational institutions of Ukraine", Politek-SOFT, 2017. [Online]. Available: http://www.politek-soft.kiev.ua/. (in Ukrainian)

[7] I. Petrovych and Yu. Rymar,"Information system of managing educational process in the UNIVERSITY: a comparative analysis", Visnyk (Official Gazette) of Lviv Polytechnic National University, №735, p. 167175, 2012. (in Ukrainian) 
[8] V. Jampol'skij, O. Petrov, I. Chudinov and V. Valentinov, Automation of management in higher school. Voronezh: Izdatel'stvo Voronezhskogo universiteta, 176 p., 1987. (in Russian)

[9] A. Celyh, D. Bobrovskij and Je. Kotov, Complex automation of University management on the basis of ASU. Taganrog: Izd-vo TTI JuFU, 126 p., 2009. (in Russian)

[10] A. Gurzhij, V. Krivcov, A. Kulik, E. Mirnaja, N. Nechiporuk and A. Chuhraj, Information-analytical management model technical higher educational institutions. Har'kov: Nac. ajerokosm. un-t "Har'kovskij aviacionnyj institut", 387 p., 2004. (in Russian)

[11] S. Karpliuk, "Information and pedagogical management of higher education: modern state and prospects of development", Scientific Herald of Uzhhorod University. Series: "Pedagogy. Social Work", №241, p. 122-125, 2017. (in Ukrainian).

\section{(C) EY-NC-SA}

This work is licensed under Creative Commons Attribution-NonCommercial-ShareAlike 4.0 International License. 